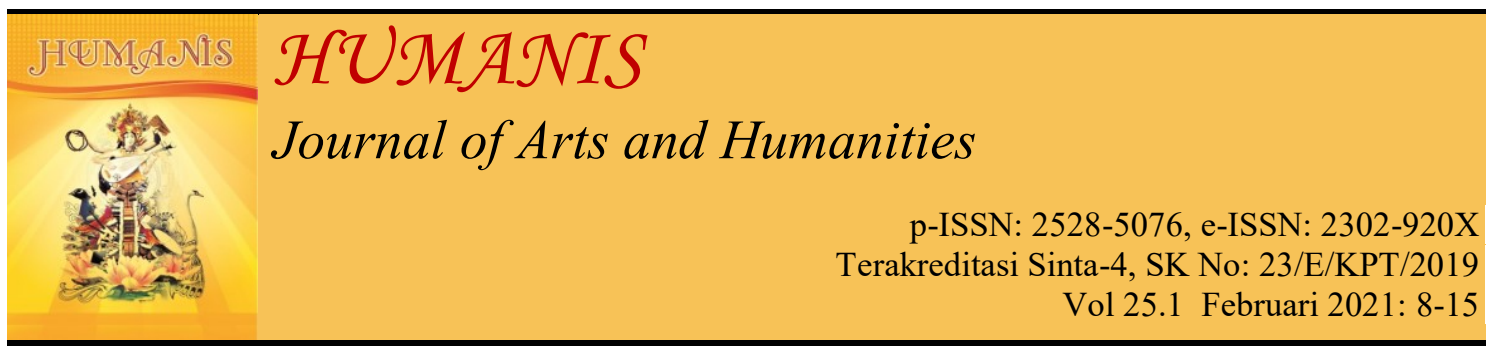

\title{
Perempuan Karir di Bawah Bayang-Bayang Kekerasan dalam Rumah Tangga di Kabupaten Badung: Suatu Analisis Gender
}

\author{
Ni Made Wiasti, Ni Luh Arjani \\ Universitas Udayana, Denpasar, Bali, Indonesia \\ Correspondence e-mail: mwiasti@yahoo.com, luh arjani@unud.ac.id
}

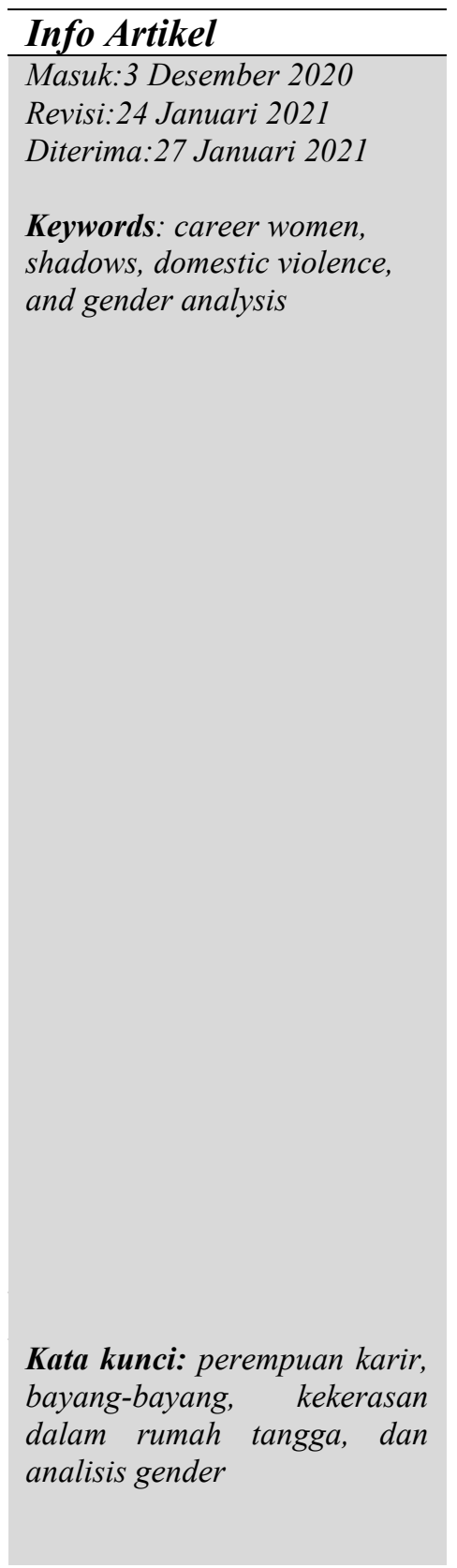

\begin{abstract}
Various attempts have been made to overcome the problem of domestic violence. However, the reality of domestic violence cases remains high. Throughout 2017 alone, a total of 142 cases were found in Bali and 90 percent of them were domestic violence cases. Meanwhile, in Badung District, during the period January to June 2017, a total of 14 cases of domestic violence were recorded. Meanwhile, there were 25 reported cases last year (2018). This study aims: 1) to know the forms of violence within the family in Badung District; 2) know the things underlying the occurrence of violence in the family in Badung District; and 3) know the coping strategies violence in the family in Badung District. This research was conducted by applying qualitative methods through data collection techniques by observation and interviews. Data analysis applied interpretive descriptive analysis. The results showed that domestic violence can be seen from various forms of violence including: physical violence, psychological violence, sexual violence and economic violence. The factors influencing the occurrence of violence include: the economic independence of the wife who does not work and the economic independence of the wife for the wife who works, infidelity, misunderstanding of myths and religious teachings about women, and a temperamental husband. Efforts to protect and control against acts of violence can be: repressive (prosecution) by criminal law through the judiciary and outside the criminal law, such as: facilitating reconciliation efforts for victims and perpetrators, providing assistance for victims in resolving cases, helping provide a safe place for victims who feel threatened, help restore self-confidence to victims, make efforts to release cases of violence experienced by victims as well as protect from threats received by victims. Preventively, this can be done through the following forms: dissemination, distributing brochures as well as installation of billboards.
\end{abstract}

\footnotetext{
Abstrak

Berbagai upaya telah dilakukan untuk menanggulangi masalah kekerasan dalam rumah tangga (KDRT). Tetapi kenyataannya kasus KDRT masih tetap tinggi. Di Bali sepanjang tahun 2017 saja ditemukan 142 kasus dan 90 persennya adalah kasus KDRT.Sedangkan di Kabupaten Badung, dalam periode Januari hingga Juni tahun 2017 saja tercatat 14 kasus KDRT yang
} 


\author{
Corresponding Author: \\ Ni Made Wiasti \\ emial:mwiasti@yahoo.com \\ DOI: \\ https://doi.org/10.24843/JH.20 \\ 21.v25.i01.p012
}

\section{PENDAHULUAN}

Tidak dipungkiri bahwa setiap keluarga memiliki cara sendiri untuk menyelesaikan masalahnya masingmasing. Apabila masalah diselesaikan secara baik dan sehat maka setiap anggota keluarga akan mendapatkan pelajaran yang berharga yaitu menyadari dan mengerti perasaan, kepribadian dan pengendalian emosi tiap anggota keluarga sehingga terwujudlah kebahagiaan dalam keluarga. Penyelesaian konflik secara sehat terjadi bila masing-masing anggota keluarga tidak mengedepankan kepentingan pribadi, mencari akar permasalahan dan membuat solusi yang sama-sama menguntungkan anggota keluarga melalui komunikasi yang baik dan lancar.
Disisi lain, apabila konflik diselesaikan secara tidak sehat maka konflik akan semakin sering terjadi dalam keluarga.

Undang-undang tentang Penghapusan Kekerasan Dalam Rumah Tangga yang merupakan perlindungan terhadap perempuan memang sudah lama disahkan (2004), akan tetapi masalah kekerasan terhadap perempuan saat ini masih cukup banyak terjadi.Setiap tahun masih saja ada laporan kasus kekerasan terhadap perempuan.Hal ini terjadi di semua daerah tidak terkecuali Bali yang katanya Pulau Sorga. Bahkan Sekretaris Asosiasi Perempuan Indonesia untuk Keadilan (LBH APIK) Provinsi Bali, Luh Putu Anggreni menyebut, kasus Kekerasan Dalam Rumah Tangga (KDRT) di Bali masih tinggi. "Sepanjang 
tahun 2017 saja kami mempunyai 142 kasus dan 90 persennya adalah kasus KDRT.Kasus Kekerasan Dalam Rumah Tangga (KDRD) di Kabupaten Badung, masih terjadi. Sedangkan di Kabupaten Badung, dalam periode Januari hingga Juni tahun 2017 saja tercatat 14 kasus KDRT yang dilaporkan. Sementara pada tahun lalu (2016) ada 25 kasus yang dilaporkan

(http://www.balipost.com/news/2017/07/ 31/16588/Di-Badung,Belasan-KasusKDRT...html).

Berdasarkan fenomena di atas, maka tujuan penelitian ini adalah mengidentifikasi dan memahami beberapa hal, yakni: bentuk-bentuk kekerasan dalam rumah tangga di Kabupaten Badung, faktor-faktor apa yang menyebabkan terjadi kekerasan dalam rumah tangga, dan strategi penanggulangan kekerasan dalam rumah tangga di Kabupaten Badung.

\section{METODE}

Penelitian ini dilakukan dengan menggunakan pendekatan penelitian kualitatif yang lebih mengandalkan teknik pengamatan, wawancara mendalam, dan studi dokumen. Dalam upaya pengumpulan data dan informasi yang dilakukan melalui langkahlangkah:penentuan lokasi penelitian, penentuan informan, pengamatan (observasi), wawancara mendalam,dan mendalami dokumen terkait. Teknik analisis data dilakukan dengan teknik analisis deskriptif interpretatif.

\section{PEMBAHASAN}

\section{Bentuk-Bentuk Kekerasan dalam Rumah Tangga (KDRT)}

Undang-undang nomor 23 tahun 2004, tanggal 22 September 2004 tentang Penghapusan Kekerasan dalam Rumah Tangga yangdisusun oleh sejumlah lembaga swadaya masyarakat dengan mengacu pada Deklarasi di atas, memuat pengertian kerasan dalam rumah tangga yang dirumuskan sebagai berikut.

"Kekerasan dalam rumah tangga adalah setiap perbuatan yang dilakukan seseorang atau beberapa orang terhadap orang lain, yang berakibat atau mungkin berakibat kesengsaraan atau penderitaan secara fisik, seksual, atau psikologis termasuk ancaman perbuatan tertentu, pemaksaan atau perampasan kemerdekaan secara sewenangwenang atau penekanan secara eknomi yang terjadi dalam lingkup rumah tangga".

Lebih lanjut berbagai bentuk kekekerasan, yakni kekerasan fisik, psikologis, seksual, ekonomi dan perampasan kemerdekaan dirumuskan sebagai berikut.

a. Kekerasan fisik adalah setiap perbuatan yang menyebabkan rasa sakit cidera, luka atau cacat pada tubuh seseorang atau menyebabkan kematian.Para informan yang mendapatkan kekerasan fisik dari suami mereka semuanya mengatakan terjadi sewaktu mereka (suami-istri) dalam keadaan bertengkar.Perselingkuhan adalah salah satu pemicu kejadian ini.Informan (sebut saja Ayu) yang bertempat tinggal di Kecamatan Abian Semal misalnya,mengungkapkan bahwa mantan suaminya adalah tipe laki-laki yang suka berselingkuh yang menyebabkannya menjadi laki-laki kasar dan temperamental.Setiap saat jika Ayu bertanya kepada suaminya terkait dengan perubahan sikap dan perilakunya yang sudah dirasakan sejak lama.Sikap dan perilakunya sangat bertentangan dengan sebelumnya yang lembut, tidak emosiaonal, tetapi kini menjadi kasar, 
dan suka mengumpat dengan kata-kata kasar, bahkan belakangan suami informan sudah terbiasa mengumpat sambil menampar, menendang dan memukul informan.

b. Kekerasan psikologis adalah setiap perbuatan dan ucapan yang mengakibatkan ketakutan, hilangnya rasa percaya diri hilangnya kemampuan untuk bertindak dan rasa tidak berdaya pada seseorang.Kekerasan psikis berat, berupa tindakan pengendalian, manipulasi, eksploitasi, kesewenangan, perendahan dan penghinaan, dalam bentuk pelarangan, pemaksaan dan isolasi sosial; tindakan dan atau ucapan yang merendahkan atau menghina; penguntitan; kekerasan dan atau ancaman kekerasan fisik, seksual dan ekonomis; yang masing-masingnya dapat mengakibatkan penderitaan psikis mulai dari tingkat ringan sampai berat. Mengacu pada konsep tersebut hasil penelitian menunjukkan kekerasan psikis atau psikologis lebih sering dan lebih banyak dialami oleh perempuan diabandingkan kekerasan fisik. Seorang informan (sebut saja Bunga) beralamat di Kecamtan Mengwi menceriterakan suaminya yang selalu mengeluarkan kata-kata menyakitkan jika jengkel sedikit saja, padahal katanya rumah tangga mereka tidak memiliki masalah serius yang memicu konflik antara Bunga dan suaminya. Oleh karena itu Bunga sering bertanya kenapa suaminya bersikap dan berkata-kata kasar. Bunga mengakui memang tidak pernah merasakan atau mengalami kekerasan karena tidak pernah dipukul, ditampar atau diperlakukan tidak baik dalam hal seksual. Tetapi kemudian Bunga mengatakan merasa sakit hati karena kata-kata kasar yang sering dilontarkan oleh suaminya ketika marah, padahal Bunga mengatakan dirinya selalu diam dan mengalah saat suaminya sedang marah.

c. Kekerasan seksual adalah tiap-tiap perbuatan yang mencakup pelecehan seksual, sampai kepada memaksa sesorang untuk melakukan hubungan seksual tanpa persetujuan korban atau disaat korban tidak menghendaki dan melakukan hubungan melalui caracara yang tidak wajar atau tidak disukai korban dan atau menjauhkan (mengisolasi) dari kebutuhan seksualnya. Pemaksaan kehendak menjelang berhubungan seks sebenarnya terjadi karena adnya ketidaksesuaian atau ketidaksinkronan keinginan antara suami dengan istri dalam berhubungan seks. Pada saat seperti ini sering terjadi penolakan para istri terhadap keinginan suami, baik karena kebencian kepada suami maupun karena alasan lelah. Alasan karena kebencian istri kepada suami yang membuat istri menolak kepada suami timbul karena para istri ini telah atau baru saja mengalami kekarasan lain, baik fisik, psikologis maupun ekonomi. Ada anggapan bahwa secara medis perempuan memiliki gerak rangsangan seksual yang relatif lebih lamban daripada laki-laki, juga memiliki hasrat seksual yang sangat dipengaruhi oleh suasana emosionalnya. Berikut adalah penuturan informan terkait dengan pengalaman mereka. Seorang informan (sebut saja Cantik) yang bertempat tinggal di Kecamatan Kuta selalu berusaha menolak ajakan suaminya karena terlanjur benci akibat kekerasan-kekerasan yang dilakukan suaminya.

d. Kekerasan ekonomi adalah tiap-tiap perbuatan yang membatasi seseorang untuk bekerja di dalam atau di luar rumah yang menghasilkan barang atau uang dan membiarkan bekerja untuk 
dieksploitasi atau menelantarkan anggota keluarga.Kekerasan ekonomi adalah yang paling sering dialami oleh para istri. Informan AC yang mengalami kekerasan fisik karena suaminya suka main perempuan dan suka menghambur-hamburkan uang sebagaimana diuraiakan di atas, dalam hal ini diberi inisial DA beralamat di Kuta Selatantelah lama menalami kekerasan ekonomi. Suami DA tidak pernah memberi uang untuk keperluan DA dan anak-anaknya. Untuk menghidupi diri dan anak-anaknya serta untuk memenuhi kebutuhan keluaraga DA berusaha bekerja serabutan dan memelihara babi yang dia peroleh dari bantuan pemerintah.

\section{Faktor-faktor yang Menyebabkan Terjadinya Kekerasan dalam Rumah Tangga (KDRT) di Kabupaten Badung}

a. ketidakmandirian ekonomi dari istri yang tidak bekerja dan kemandirian ekonomi istri dari istri yang bekerja.Selama ini berbagai dugaan dan beberapa hasil penelitian menemukan bahwa ketergantungan istri kepada suami secara ekonomis karena status istri tidak bekerja merupakan faktor yang mendorong suami bertindak semaunya bahkan melakukan kekerasan terhadap istri. Tetapi dalam penelitian ini terlihat kenyataan yang relatif berbeda. Selain ketidakmampuan istri dibidang ekonomi, kemampuan ekonomi istri justru juga menyebabkan suami melakukan kekerasan terhadap istri. Jenis-jenis kekerasan yang dilakukan terhadap istri yang berasal dari kemampuan ekonomi istri pun sangat kompleks meliputi kekerasan ekonomi, fisik, psikologis dan seksual.Bisa dikatakan, baik istri yang mandiri secara ekonomi, maupun yang tidak mereka sama-sama berpeluang menagalami tindak kekerasan dalam ruamah tangga.

b. Perselingkuhan suami dengan perempuan lain. Perselingkuhan suami dengan perempuan lain atau menikah lagi menjadi asalah satu penyebab terjadinya kekerasan dalam perkawinan. Perselingkuhan dan menikah lagi dapat menyebabkan istri mengalami kekerasan fisik, ekonomi, psikologis dan sekual. Istri yang menegur suaminya yang selingkuh bukannya mendapatkan sambutan yang baik malah mendapat makian, hinaan, pukulan, lemparan dan lainlain. Ayu misalnya, dilempar dengan piring dan hampir saja ditendangnya tetapi ditangkis, karena menegur suami yang kurang memperhatikan rumah tangga akibat sibuk mengurus perempuan idamannya.

c. Campur tangan pihak ketiga. Campur tangan anggota keluarga dari pihak suami khususnya, terutama ibu mertua dan ipar-ipar, merupakan salah satu penyebab timbulnya kekerasan antara suami-istri. Bentuk-bentuk kekerasan yang timbul akibat campur tangan pihak keluarga antara lain: kekerasan fisik, psikologis dan ekonomi. Jika mertua yang suka menjelek-jelekkan menantunya dapat menyebabkan anaknya melakukan berbagai tidak kekerasan terhadap istrinya, seperti: memukul, menampar, mencaci maki bahkan tidak memperhatikan kebutuhan ekonomi keluarga. Seperti kasus Dinda dan Danti. Mereka ratarata mengalami kekerasan dan menjadi sasaran kemarahan suaminya karena ibu mertua mengadu yang tidak-tidak pada suami mereka. Sampai akhirnya beberapa dari informan meminta pertolongan dari saudara mereka untuk untuk mengetengahinya persoalan yang dihadapi. 


\section{Upaya Penanggulangan Kekerasan Dalam Rumah Tangga (KDRT) di Kabupaten Badung}

Selama ini masih ada anggapan bahwa konflik dan kasus-kasus kekerasan dalam rumah tangga dianggap sebagai persoalan dan urusan domestik. Menjunjung dan menjaga nama baik keluarga merupakan fenomena ideal bagi masyarakat pada umumnya. Hal inilah yang seringkali menjadi acuan bagi seseorang yang mengalami kasus KDRT untuk tidak melaporkannya pada pihak yang patut menanganinya. Seperti istilah di Bali jika melaporkan kasus yang terjadi di keluarga sama dengan "makecuh marep menek" (berludah ke atas) yang akhirnya diri sendiri yang kena ludahnya. Namun demikian, pemerintah tidak mau tinggal diam jika di masyarakat terindikasi sering terjadi kasus kekerasan dalam rumah tangga karena hal ini akan membawa citra buruk di mata masyarakat lainnya.

Untuk itu pemerintah turun tangan untuk mencegah terjadinya permasalahan KDRT melalui berbagai upaya. Upaya perlindungan dan penanggulangan terhadap tindak kekerasan dapat bersifat: pertama, represif (penindakan). Upaya perlindungan dan penanggulangan terhadap tindak kekerasan yang bersifat represif (penindakan) dengan hukum pidana melalui peradilan maupun di luar hukum pidana, seperti: memfasilitasi upaya damai bagi korban dan pelaku, memberikan pendampingan pada korban dalam penyelesaian perkara, membantu memberikan tempat yang aman bagi korban yang merasa terancam, membantu mengembalikan rasa percaya diri pada korban, melakukan upaya pembebasan dari kasus kekerasan yang dialami korban, melakukan perlindungan dari ancaman yang diterima korban, mengupayakan pemulihan kesehatan secara fisik atau non-fisik. Kedua, pencegahan bersifat preventif (pencegahan). Secarapreventif tindak kekerasan dalam rumah tangga dapat dilakukan melalui bentuk-bentuk: sosialisasi, penyebaran brosur, pemasangan billboard, dan baner. Pencegahan secara preventif kekerasan dalam rumah tangga ini sesungguhnya juga bisa dilakukan melalui lembagalembaga masyarakat atau lembaga adat. Hal ini bisa dilakukan mulai dari lembaga terkecil dan utama yakni: keluarga, dadia (keluarga luas), sekaa, dan kelompok sosial lain yang ada di tingkat banjar dan desa.

\section{SIMPULAN}

Bentuk-bentuk kekerasan dalam rumah tangga (KDRT) meliputi: kekerasan fisik (ditampar, ditendang), kekerasan psikis (dicaci maki, dibentak), kekerasan seksual (pemaksaan kehendak menjelang berhubungan seks) dan kekerasan ekonomi (suami tidak pernah memberi tahu berapa sebenarnya gajinya dan juga tidak pernah menyerahkan pengelolaan uang kepadanya) .

Faktor-faktor penyebabkan terjadinya kekerasan dalam rumah tangga (KDRT), antara lain: yakni pertama, perselingkuhan suami dengan perempuan lain, kedua, ketidakmadirian ekonomi pada istri yang tidak bekerja dan kemandirian secara ekonomi pada istri yang bekerjai kedua, campur tangan keluarga, keempat pemahaman yang salah terhadap mitos dan pemahaman ajaran agama, dan kelima, kebiasaan suami yang tempramental.

Upaya penanggulangan KDRT dilakukan oleh berbagai komponen terkait seperti P2TP2A Kabupaten Badung, Polres, Kantor Pemberdayaan Perempuan Kabupaten Badung, dan Pemberdayaan Kesejahteraan Keluarga (PKK), serta peran desa adat. Penelitian selanjutnya lebih mendalam terkait dengan persoalan kekerasan dalam rumah tangga. 
DAFTAR PUSTAKA

Arivia, Gadis. (2002) Perempuan Sebagai Pemelihara Perdamaian. Jurnal Perempuan vol. 26 th 2002.

Ahmad Toriq - detikNewsSelasa, 20/12/2011 11:42 WIB

Allennellakuraini. (2013). File://E://PSW 2013/faktor penyebabKDRT_Allennella kuraini.htm

Badan Pemberdayaan dan Anak Provinsi Bali, (2012).Laporan Tahunan Hasil Kegiatan TKTP Provinsi Bali.Tahun 2012.

Budiman, Arief, (1981). Pembagian Kerja Secara Seksual: Sebuah Pembahasan Sosiologis Tentang Peran Wanita Di Dalam Masyarakat. Jakarta: Gramedia.

Doni Aprian. http://news.okezone.com/read/2013

Fakih, Mansour. (2020). Analisis Gender dan Transformasi Sosial. Yogyakarta: Insist Press.

Foucault, Michel. (1997). Seks dan Kekuasaan: Sejarah Seksualitas. RahayuS. Hidayat (Penerj.) Jakarta: Gramedia Pustaka Utama.

Goltom, Maldin, (2012). Perlindungan Hukum terhadap Anak dan Perempuan.Bandung: PT Refika Aditama.

https://badungkab.bps.go.id. (Badan Pusat Statistik Kabupaten Badung, Bali) Diakses pada 8 Mei 2019.

http://www.thefreedictionary.com/Child+ abuse. (Wikipedia bahasa Indonesia, ensiklopedia bebas) Diakses pada 15 September 2010.

http://.jurnalskripsi.com, 2009.

http://www.thefreedictionary.com/Child+ abuse. (Wikipedia bahasa Indonesia, ensiklo pedia bebas) Diakses pada 15 September 2010.

Kementerian Pemberdayaan Perempuan dan Perlindungan Anak.2010. Melindungi Hak Anak dari
Kekerasan.www.menegpp.go.id/ (@4)

Kementerian Pemberdayaan Perempuan dan Perlindungan Anak. 2010. Glosari Perlindungan Anak. www.menegpp.go.id/ (@5)

Komisi Perlindungan Anak Indonesia. Id.wikipedia.org/wiki/

Komisi_Perlindungan_ Anak Indonesia

Kepolisian Negara RI Daerah Bali Resort Kota Denpasar, 2011-2013. Data Kejahatan/Kekerasan terhadap perempuan dan Anak di Wilayah Kabupaten Badung yang Ditangani Polresta Denpasar. Tahun 20112013.

Leeb, R.T. (2008) (Wikipedia bahasa Indonesia, ensiklopedia bebas) http://www.cdc.gov/ncipc/dvp/CM P/CMP-Surveillance.htm. Diakses pada 20 Oktober 2008.

Lembaga Perlindungan Anak Jawa Barat. Penanganan Kasus Kekerasan dan Penelantaran Anak (Dalam Konteks Sistem Rujukan). Slide Tindak kekerasan 2012.

Nadya, Ita F., (1998). "Akar Kekerasan terhadap Perempuan dari Perspektif Gender" dalam Kekerasan terhadapPerempuan". Yayasan

Lembaga Konsumen Indonesia dan The Ford Foundation.

Puspitawati,Herien. (2012). Gender dan keluarga konsep dan realita di Indonesia. Bogor: IPB Press.

Sri Sumarwani, (2011). Kekerasan pada Anak Bentuk, Penanggulangan dan Perlindungan pada Anak Korban Kekerasan.WordPress. Blog Unnisula.

Tilaar, H.A.R. (2009). Kekuasaan dan Pendidikan: Manajemen Pendidikan Nasional dalam Pusaran Kekuasaan. Jakarta: Rineka Cipta

Undang-Undang Republik Indonesia Nomor 23 Tahun 2004 tentang 
Penghapusan Kekerasan Dalam Rumah Tangga.

UNICEF Indonesia. Sekilas Perlindungan Anak.

http://www.unicef.org/indonesia/id/ Wahab, Rochmat. Tanpa Tahun.Kekerasan Dalam Rumah Tangga: Perspektif Psikologi dan Edukatif.

http://staff.uny.ac.id/site/default/fil es/penelitian 